\title{
THE POWER OF THE GOSPEL VICTORIOUS OVER THE POWER OF EVIL IN ACTS OF THE APOSTLES
}

\author{
Dirk van der Merwe \\ New Testament \& Early Christian Studies \\ University of South Africa
}

\begin{abstract}
This research focuses on how the author of Acts managed, rhetorically, to communicate his ideological standpoint regarding "the power of proclaiming the good news about the kingdom of God and the power that exist in the name of Jesus Christ" (8:12). In three related texts $(8: 4-25 ; 13: 1-12 ; 19: 1-20)$ he addresses the practices of magic which occurred in the society or even in the early Church, to prove to his readers that the proclamation of the gospel overpowers the practice of evil. In these texts there are references to magic or magicians (Acts 8:4-25, magei , mageuw 13:1-12, mago (bis); 19:8-20, praxei , parierge ) which refer to the occurrences of magical practices. In

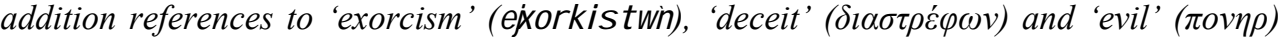
also occur. Complementary to this is the considerable frequency of references to the proclamation of the gospel and the occurrences of miracles (duma mi and $\mathrm{s} \mathrm{h}$ mei à) within the same historical context. When these texts are compared with one another, it becomes evident that other similarities also occur. The reason for making such a comparison is to point out how the author used the interaction of events such as 'magic,' 'exorcism of evil spirits,' 'miracle' and 'gospel proclamation' to explain his understanding of the supreme power of the 'gospel' as victorious over the power and influence of 'evil.'
\end{abstract}

Key Words: Magic, Miracles, Proclamation of the Gospel, Convince, Rhetoric

\section{Introduction}

Throughout the books of the New Testament the tension between light and darkness, good and evil, right and wrong conduct have been emphasized and spelled out by their authors. This tension and antithesis is spelled out in different ways, relating to the content and purpose of the particular document. In Acts of the Apostles there is no deviation from this. Heavily burdened with information to emphasize the power of the gospel over the power of evil, the central force which powers the design of Acts is certainly a prophetic mission laid on the characters in the opening scene (1:8). All this is a demonstration of power. It is necessary because some Christian believers continue to seek spiritual power from sources other than Jesus. ${ }^{1}$ They practice a bifurcated religion characterized by dual allegiance and a syncretistic understanding of truth (Talbert 1997:177). The author's (hereafter Luke) ${ }^{2}$ renunciation of magic $(8: 19-24 ; 13: 6-12 ; 19: 13-19)$ is part of a repudiation of such a trajectory continuing in the ancient church: Ignatius of Antioch says that with Christ's birth "forward every sorcery and every spell was dissolved..." (Eph 19:3); Didache 2.2 says,

\footnotetext{
According to Kanda (1974:209) the incident in Acts 19:18-29 is a description of the Christians who openly confessed before the congregation their involvement in magic.

2 Scholars are quite unanimous that Luke was the author of Acts of the Apostles. See Lenski 1961:9; Haenchen 1971:90ff; Munck 1981:xxix; Conzelmann 1987:xl; Barrett 1994:30; Zmijewski 1994:17ff; Dunn 1996:xi; Witherington 1998:58; Gaventa 2003:27.
} 
"you shall not practice magic; you shall not use enchantments"; Barnabas 20:1 says that the way of darkness and death includes enchantment and magic; Tertullian says that "After the Gospel, you will nowhere find..., enchanters, diviners, or magicians, except as clearly punished" (On Idolatry 9).

This research is to point out how Luke tries to combat magical practices in the early church. He wants to show how the power of the gospel is stronger than, even victorious over, the practices of magic. Hence, this research (1) will start with an attentive reading of the identified texts in which they will be compared with one another to detect the main shared and focal events that occur in these texts; (2) then the shared and focal events in these texts will be investigated in their socio-historical and literary environments for a better understanding of the meaning of these events and the functional references of it in the text. (3) Finally, the rhetorical device, used by Luke to convince his readers to break with magic and to accept the word of the Lord, will be discussed briefly.

\section{The Attentive Reading of Three Identified Texts}

A survey for relevant and applicable texts, where there are explicit references to magic (mageia, mageuw 8:9, 11; mago (bis) - 13:6, 8; praxei , parierge 19:19), ${ }^{3}$ has led to the identification of only three distinctive pericopae in Acts of the Apostles (8:4-25; $13: 1-12 ; 19: 8-20)$. Each of these texts forms a pericope unit. The events in these pericopae are pointed out in this table according to the sequence they occur in the text.

\begin{tabular}{|c|c|c|}
\hline Acts 8 & Acts 13 & Acts 19 \\
\hline & Holy Spirit called \& sent out & Holy Spirit came upon \\
\hline & $\begin{array}{l}\text { tried to turn the proconsul away } \\
\text { from the faith }\end{array}$ & $\begin{array}{l}\text { some stubbornly refused to } \\
\text { believe and spoke evil of the Way }\end{array}$ \\
\hline 1) Proclaim gospel & Proclaim gospel & Proclaim gospel \\
\hline $\begin{array}{l}\text { 2) Miracles (sick people } \\
\text { cured), exorcism, }\end{array}$ & $\begin{array}{l}\longrightarrow \text { Miracle (retributive) } \\
\text { (Elymas became blind) }\end{array}$ & $\begin{array}{l}\text { Miracles (sick people cured), } \\
\text { exorcism }\end{array}$ \\
\hline 3) Unclean spirits & & Evil spirits \\
\hline 4) Magic reference & $\begin{array}{l}\text { Reference to Elymas the } \\
\text { magician }\end{array}$ & \\
\hline 5) Believe / baptized & Believe & Believe \\
\hline $\begin{array}{l}\text { 6) Amazed when saw } \\
\text { signs and miracles }\end{array}$ & $\begin{array}{l}\text { Astonished at the teaching } \\
\text { about the Lord. }\end{array}$ & $\begin{array}{l}\text { Awestruck about the exorcism / } \\
\text { non exorcism Praised the name } \\
\text { of Jesus }\end{array}$ \\
\hline \multicolumn{3}{|l|}{$\begin{array}{l}\text { Holy Spirit received } \\
\text { and given }\end{array}$} \\
\hline & Repent from their wickedness & Magical practices stopped \\
\hline $\begin{array}{l}\text { Keep on proclaiming good } \\
\text { news }\end{array}$ & & $\begin{array}{l}\text { Word of the Lord grew } \\
\text { mightily and prevailed }\end{array}$ \\
\hline
\end{tabular}

This analysis shows the coherence of events that bind these three pericopae. From this analysis it is evident that the same basic literary structure occurs in all three pericopae with

In Acts $5: 16 ; 16: 16-21$ there are also references to evil spirits. The reason for not choosing them for investigation in this research is due to the fact that none of the elements and antithetical events, as in the selected texts, occur there and that those that do occur are not well developed. Although both texts concern exorcism, the references to spirits in these texts do not refer to 'possession' by the spirits. Porter (2007:118f) suggests that the event in Acts 14:8-20 also mirror patterns of magical activity. 
slight differences in each one. This comparison convincingly shows a close relatedness between these three texts regarding the vocabulary, concepts and basic literary structure. In this research the conjunction and interaction of these major events, as pointed out in the above analysis, will be examined in order to point out how Luke does this to convince his readers regarding the supremacy of the power of the Gospel over the power of evil. ${ }^{4}$

\section{The Interpretation of the Focal Events}

\section{Defining Magic and Miracle}

Magic: The noun magei (Acts 8:11) can be translated as 'magic; plural magic arts, sorceries" (Friberg [et al] 2000:251). It can also be translated as "sorcery, witchcraft, black magic" (Delling 1967:359); the verb mageuw refers "to practice magic, presumably by invoking supernatural powers - to practice magic, to employ witchcraft, magic" (Louw \& Nida 1988:545, §53.96). The noun ma g $0 \sim^{6}(13: 6,8$, a derivative of ma geuw) refers to "one who practices magic and witchcraft - 'magician'." The adjective perierga (19:19) used in conjunction with the verb praxant wn refers to "the use of magic based on superstition 'magic, witchcraft”" (Louw \& Nida 1988:545, §53.99; Bruce 1989:367). From these definitions magic is associated with idolatry, with the demonic (see also Garrett 1989:1317) and with evil (Gaventa 2003:192). In ch 13 Paul refers to Bar-Jesus (Elymas), a magician, as 'son of the devil.'

Miracle: Luke uses two different nouns (dunami and shmeià) to refer to miracles in these passages: (1) dunami : according to Danker (2000:263) it refers, in both texts (8:13; 19:11), to "a deed that exhibits ability to function powerfully, deed of power, miracle, wonder." (2) s h mei à : The lexicographical meaning, according to Danker (2000:920) is "an event that is an indication or confirmation of intervention by transcendent powers, miracle, portent."

Meier (1994:512) defines a miracle as: “...an unusual, startling, or extraordinary event that is in principle perceivable by any interested and fair-minded observer, (2) an event that finds no reasonable explanation in human abilities or in other known forces that operate in our world of time and space, and (3) an event that is the result of a special act of God, doing what no human power can do." ${ }^{, 7}$ Miracle-working was the ultimate expression of mediated divine power (cf. Reimer 2002:247). Thus a clear distinction exists between magic and miracle.

$4 \quad$ When reading these three texts, the readers in early Christianity would have become aware of the "warfare terminology' being used by Luke to make the reader aware of the continuous cosmic battle ${ }^{4}$ between the Kingdom of God and the kingdom of evil. Gaventa (2003:195) refers to it as a "larger drama in which the Gospel of God battles the power of Satan." Luke uses this terminology to create a setting in which the power of the gospel is demonstrated and has to be understood. The following is a list of this warfare terminology used by the author: The power of God (h)duna mi t ou 'qeou, 8:10); Proclaiming the good news (eujag gel izomenw 8:12,25); Opposed (a nqi s thmi 13:8); Enemy of all righteousness (ej qre;pa s $\mathrm{h}$ dika i os unh , 13:10); Leap on / mastered (kat a kur i eus a , 19:16); Overpowered them (i c us en 19:16); Wounded, fled out naked, (t et $r$ a uma t is menou , 19:16); Burned them (kat eka i on 19:19); Mightily (i 5 c uen 19:20).

See Meier (1999:548f) for an excellent comparison between characteristics of 'miracle' and 'magic.'

$6 \quad$ In Ac. 13:6, 8 mago is used of a Jew along with $\rightarrow$ y eudop r of $h t h \sim$.

7 See Meier (1994:512f) for an elaboration on each of these points. 


\section{Occurrences of Magic and Miracles}

Magic: Magic was practiced widely in antiquity. ${ }^{8}$ The most references to magic in the New Testament writings are found in Acts. ${ }^{9}$ The three references of significance which refer here pertinent and explicitly to magicians or magical practices $a^{10}{ }^{10}$ : (a) Simon, commonly referred to as Simon Magus (Acts 8:19-24). He practised spectacular magic in Samaria, but professed conversion in response to Philip's preaching. (b) Bar-Jesus, or Elymas ( Acts 13:4-12 ). He was a magician in Cyprus in the service of Sergius Paulus, the proconsul. (c) The following magical practices are referred to books of perierga magic arts, sorcery, witchcraft): In the light of Acts 19:18, 19 we may assume that the books that were burned were books of perierga.

Miracles: References to miracles also occur widely in antiquity. ${ }^{11}$ Meier (1994:509-645) gives a sound explanation of how miracles in antiquity should be understood and explained. The most references to miracles in the New Testament writings are found in the four Gospels. A number of miracles also occur in Acts of the Apostles.

For the purpose of this research it is necessary to refer to the miracles referred to in Acts 8, 13 and 19. (a) In Acts 8:6-8 Luke connects Philip's activity in Samaria with healing and exorcism. (b) In Acts 13:11 Paul performs a retributive miracle when he curses BarJesus/Elymas with blindness - "immediately mist and darkness came over him." (c) In Acts 19:11-12 Luke refers to how God did extraordinary miracles through Paul. These miracles

8 For a survey of data, literature and practices see Bohak, G 2008. Ancient Jewish magic: a history. New York: Cambridge Univ. Press; Graff, F 2007. Magic in the Ancients World. Cambridge, Mass: Harvard University Press; Labahn, M \& Peerbolte, BJL (eds.) 2007. A Kind of Magic. London: T\&T Clark; Janowitz, N 2001. Magic in the Roman World: Pagans, Jews, and Christians. London: Routledge; Marston, J M 2007. Language of Ritual Cursing in the Binding of Prometheus. Greek, Roman, and Byzantine Studies 47, 121-133 (http://www.escholarship.org/uc/item/2zc4h1kn) 26/01/2010; Pinch, G 2006. Magic in ancient Egypt. London: British Museum; Mastrocinque, A 2005. From Jewish magic to Gnosticism. Tübingen: Mohr Siebeck; Klutz, TE (ed.) 2003. Magic in the Biblical world: from the rod of Aaron to the ring of Solomon. London: T\&T Clark Internationa; Dickie, M 2003. Magic and magicians in the Greco-Roman world. New York: Routledge; Mirecki, P \& Marvin, M (eds.) 2002. Magic and ritual in the ancient world. Leiden: Brill; Klauck, H-J 2001. Magic and paganism in early Christianity: the world of the Acts of the apostles. Edinburgh: T\&T Clark; Aune, DE 1980. Magic in Early Christianity, pages 1507-57 in Aufstieg und Niedergang der römischen Welt: Geschichte und Kultur Roms im Spiegel der neueren Forsc II/23.2 edited by W Haase. Berlin: de Gruyter; Hull, J M 1974. Hellenistic Magic and the Synoptic Tradition, SBT Second Series 28, 5-44.

9 The following terminology also occurs in the New Testament: (1) f a r mak $\sim$ (Rev 21:8; 22:15) and f a r makei a (Gal 5:20; Rev 9:21;18:23). They can be translated as magician, mixer of potions. A basic meaning of medicine, magic potion and poison give the underlying idea of the words. (2) gobt e (2 Tim 3:13): it has the meaning of sorcerer, juggler. In classical Greek it meant a magician.(3) p uqwna (Acts 16:16): Python, although connected with the Delphic oracle it later came to designate a spirit of divination and also a ventriloquist who was thought to have such a spirit inside his / her belly. (4) epa s ka nen (Gal 3:1): The meaning is to cast a spell by what is called the evil eye ("Who has bewitched you ...?") (see Brown 1976:558f).

10 See footnote 4 regarding other texts in Acts.

11 For a survey of data, literature and practices see Eve, E 2002. The Jewish context of Jesus' miracles. Sheffield: Sheffield Academic Press; Cotter, W 1999. Miracles in Greco-Roman antiquity: a sourcebook. New York: Routledge; Cavadini, JC 1999. Miracles in Jewish and Christian antiquity: imagining truth. Notre Dame: University of Notre Dame Press. Royster, D 1999. The miracles of Christ. New York: St. Vladimir's Seminary Press; Ashton, M 1995. Miracles, wonders and signs. Birmingham: Christadelphian; Latourelle, R 1988. The Miracles of Jesus and the theology of miracles. New York: Paulist Press; Meier, JP 1994. A Marginal Jew: Mentor, Message and Miracle (Volume II). New York: Doubleday; MacRae, G 1965. Miracle in the Antiquities of Josephus, pages 129-47 in Miracles: Cambridge studies in their philosophy and history edited by Moule, CFD. London: AR Mowbray; Clark, KH 1983. Miracle in the early Christian world: a study in socio-historical method. New Haven: Yale University Press. 
are also connected with healing and exorcism. These miracles set up a dramatic contrast with 'some itinerant Jewish exorcists' who failed to perform an analogous act. These two opposite events will now be discussed in juxtaposition as they occur in the text.

\section{Practicing Magic and Performing Miracles in Acts}

Acts 8: In this pericope Luke wants to emphasize in scene one (8:5-13) that the power of Jesus' name is greater than that of magic (Talbert 1997:83). In vv 5-8 the focus is on Philip and the Samaritans to whom Philip proclaimed the Messiah. The crowds "gave heed to what was said ... when they heard him and saw the signs which he did. For unclean spirits ... came out of many ... and many who were paralyzed and crippled people were healed" (vv 6b-7). In $v 7$ two things are pointed out: (1) that the unclean spirits came out of people and (2) that they cried out as they did so. Luke wants to emphasize that the battle with unclean spirits reflects the battle between the followers of Jesus and evil. Exorcism signals here the power of God over the realm of Satan. This prepares the reader for the conflict with Satan which is implicit in the Simon story (cf. Luke 10:17-20; see Gaventa 2003:136).

In Acts 8:9-11 Luke introduces a new person named Simon, an inhabitant of the city and presumably a Samaritan. He tells us twice, in vv 9 and 11, that he had practiced magic $^{12}$ and had literally astonished the people of Samaria with his magical tricks. He himself asserts that he is 'someone great' ( $v$ 9), and the meaning of this claim becomes clearer when we hear the people acclaim him to be "that power of God, which is called Great" (v 10). ${ }^{13}$

Although a contest between Philip and Simon was expected, Simon admits in v 13 defeat all along the line before any contest actually breaks out. Simon acknowledges Philip's superiority and comes to faith and accepts baptism. He himself was 'astounded' by the signs and wonders worked by Philip. This is in accord with his own activity as worker of miracles ( $\mathrm{v} 11)$. A better testimony there could not be to the superiority of the power of Jesus over magic. The thrust of scene one then is the superiority of the name of Jesus to magic (vv 5, 12).

In scene two (14-25) the point emphasized is that the power of the Holy Spirit through which the miracles were performed is not a commodity to be bought. There is in Acts no set procedure for reception of the Holy Spirit. ${ }^{14}$ This narrative wants to say that the gift of the Holy Spirit cannot be captured in any set procedure. According to Luke 11:13, God gives the Spirit (Talbert 1997:86). ${ }^{15}$

Verses 18-19 reveals the fact that Simon, although baptized, has not transcended his magical past. He offers the apostles money to buy this 'power' (v 19). Magic seems here to

12 See also Justin, 1 Apology 26:2; 56:1-2; Dialogue 120:6; Acts of Peter 2:4, 6; 4:8; 6:16-17, etc.; PseudoClementine, Homilies 2:22.3; 2:24.1; Origen, Contra Celsus 1.57; sometimes as a Gnostic (Justin, 1 Apology 26:3; Dialogue 120:6; Irenaeus, Against Heresies 1.12.1-4; etc.).

13 In the second century Gnostic groups existed who called themselves Simonians who asserted that Simon Magus was their founder. The church fathers who attacked heresies took this further and made Simon Magus the founder of gnosis as a whole. Because of this assumption Klauck (2000a:17) took a neutral stand and asserts that the best option should be to leave the picture of Simon as open as possible.

14 In 2:38 (repent, be baptized, and receive the Holy Spirit), the gift of the Holy Spirit seems to be linked with baptism; in 8:15-17 the bestowal of the Spirit comes after baptism through the laying on of hands (cf. also 19:5-6); in 10:44-48 the Spirit is poured out in connection with Peter's preaching prior to baptism (cf. 1 Cor 2:1-4; Gal 3:1-5; 1 Thess 1:5) which seems to indicate this was the procedure in the Pauline churches; in 9:1718 the reception of the Holy Spirit appear to be in connection with the laying on of hands before baptism.

15 It would be a mistake to take Acts 8 as a paradigm of Messianic experience. God is free; experience varies. 
be mechanical. It views the Spirit as a commodity that can be bought and sold. Simon is willing to pay. This incident infers that Simon, although baptized, has not yet received the Spirit (see v 15).

This bid of Simon to receive the Spirit points out the matter of lapsing. ${ }^{16}$ Experiences have taught Luke that some people do in fact take the decision of faith too superficially. Therefore, that magic was still practiced in some churches (19:18-19), Peter immediately reprimands Simon that the Spirit is a free gift from God and must not be devalued to an object of commercial transactions.

In his response Simon acknowledges (v 14), when he was cursed by Peter, the power of the gospel over his ability of being a magician.

Acts 13: When Paul and Barnabas came to Cyprus, Paul confronts a certain magician, also referred to by Luke as a Jewish false prophet, named Bar-Jesus (v 6). He was with the proconsul, Sergius Paulus, who requested Paul and Barnabas to share God's message with him (v 7). This request was opposed by the magician Bar-Jesus whose name is translated as Elymas. ${ }^{17}$

In $\mathrm{v} 6$ he starts to describe him as a magician. ${ }^{18}$ Luke also adds a second attribute, that of a false prophet. Evil is involved here in the attempt of Elymas to deter Sergius Paulus from hearing the gospel. Again this narrative reflects a larger drama in which the gospel of God battles the power of Satan (cf. Gaventa 2003:195).

After looking at the identity of Bar-Jesus, we still have to consider the contest between him and Paul. Paul is 'filled with the Holy Spirit'. He gazed penetratingly ${ }^{19}$ on Bar-Jesus then formulates an attack consisting of a rhetorical question (v 10) and the infliction of punishment (v 11). He also asks him “....will you not stop making crooked the straight paths of the Lord?" As punishment, for blocking the path of the Lord, the hand of the Lord comes upon him (v 11). The metaphor of blinding has now been put into action in this passage. Bar-Jesus was, however, nothing more than a blind man leading the blind, and is now physically blinded.

Then the proconsul came to faith (v 12). The reasons for this, was that he has seen the miracle and that "he was astonished at the teaching about the Lord." The miracle of blindness performed through Paul, brings astonishment, but it is the message, the gospel, the word of God (v7) that is decisive. The 'word' proves its superiority. Each time it is the proclamation of the Christian message that wins the trial of strength, relying not so much

16 Luke has portrayed such a lapsing metaphorically in: Luke 8:4-14; Acts 5:1-11. This also seems to be the case with Simon Magus. The sudden prospect of quick profits has made him forget his initial enthusiasm for the new faith, so that he lapses into old patterns of behaviour. But unlike the typical professional magician the apostles and disciples of Jesus perform their miracles without payment. They demand no fee, and rejected any if it was offered. They themselves lead a poor and modest life (see also Acts $3: 6 ; 20: 33$ ).

17 See Porter (2007:117) on his explanation of the relation between these two names of the magician.

18 This word was reserved, on the basis of its Persian origin, to wise men from a priestly caste. It can be used in a neutral manner to designate astrologers, interpreters of dreams, soothsayers, healers and workers of miracles. It also has the negative connotation of charlatan, trickster, mountebank or con man. Luke notes only the sombre reverse side of the term, employing it as a weapon to discredit opponents of whom he disapproves. Conzelmann (1987:100) points out that the form, Elymas, is not widely known (see BDAG), although an inscription exists with the name hl ei m (OGIS 594). According to Porter (2007:117) there is also a magical name (or magical word) used in a number of magical documents, eulamo (PGM III.57; VII.401; IX.8; XVI.18; etc.) that has similarities as well.

19 The verb af eni s a has the meaning of "stare at, look intently, gaze, fix one's eyes" (Swanson 1997: GGK867). It is employed here and nine more times in Acts. 
on a superior miraculous power, but rather on the message of salvation which it brings (Klauck 2000a:54; see also Bruce 1989: 165).

Acts 19: Luke introduces the events in this pericope with an ardent reference to "God did extraordinary miracles by the hands of Paul" (v 11). This reference tends to present Paul as a superior worker of miracles and also to ward off potential misunderstanding of Paul being some religious super human.

In verse 12 Luke describes the miracles. People are healed from their diseases while evil spirits also came out of them. In his description of these miracles Luke intends to direct it into correct theological channels by means of his reference to the working of God (v 11), which presents the human messenger as only an instrument (Klauck 2000a:98?). The healings by Paul take place within the context of God performing extraordinary events through Paul's hands (v 11) ${ }^{20}$ (Porter 2007:119).

Verses 13-16 describe an unsuccessful exorcism. According to this text (vv 13-14) there were also other professionals (itinerant Jewish exorcists, seven sons of a Jewish high priest named Sceva) who issued orders to spirits. ${ }^{21}$ The characteristic in this case is that these exorcists employ the name of Jesus ${ }^{22}$ as a means to command the spirits ( $\left.\mathrm{v} 13\right)$. They did this because Jesus and his disciples had the reputation of successful miracle-workers. Others desired to unlock their secrets and profit from them (Klauck 2000a:99). ${ }^{23}$ The spirit dismisses every claim they made to authority as exorcists. In contrast to Paul, they have usurped the name of Jesus, to which they have no rights, so that it is impossible for them to expel the demon who stays put.

The reason why they failed was that they attempt to benefit themselves of the power that they have seen displayed by God through Paul. They invoke the language of magic: "I command (0 kiøw) ${ }^{24}$ you by Jesus whom Paul preaches" (v 13). The use of of ki zw ${ }^{25}$ is common in the magical papyri and related texts, both Jewish and pagan. Hence, the sons of Sceva are clearly meant to be seen as invoking a magical formula to be able to command

20 When Klauck (2000a:98) says that "ultimately, it [this episode] is all a question of interpretation," he loses the crux of this antithetical parallelism of events.

21 Jewish exorcists are hinted to the Gospel (Lk 9:49; 11:19). Flavius Josephus (Jewish Antiquities 8, 42-49) too is familiar to them. He describes how a Jew named Eleazar employed recipes by Solomon to treat a possessed man before the emperor Vespasian, making a tremendous impression upon those present.

22 Kanda (1974:208) is of opinion that the comparison between the sons of Sceva and Paul in Acts 19 is not necessarily to illustrate Christianity's superiority over magic. According to him it is to express the legitimate use and authority of the nomen sacrum in miracles. This is not really true. When one consider the entire literary context (19:1-20) and the reaction of the people in the end it also certainly demonstrates that the proclamation of the gospel has authority over the power of evil.

23 Sometimes magicians claim to invoke the spirits of persons who had recently died and to use the power of the dead for their own purposes; this could lead to the suspicion that Jesus' disciples achieved their effects by uttering the name of Jesus - who was dead - in order to invoke his spirit. Therefore, it seems a good idea to imitate what they were doing (Klauck 2000a:99).

24 See also Paris Magical Papyrus IV.3029: "I command you with rash words"; also 3033-41; 3045-46, 305261, 3065-66, 3069, 3075-79 (See Deissmann 1927:254-64 for text and translation). This magic language also occurs on the lead tablet from Adrumetum, upon which a lengthy Jewish magical text was written. See lines 1-2: "I command you, demonic spirit lying here, in the name of the holy Aoth Abaoth the god of Abraham and of Jao that of Jakou." See also lines 8-12, 15-119, 23-25, 27-28 and 32-33 (see Deissmann 1988:273-79 for the text and translation). According to Deissmann can it be taken for granted that the magic language on the lead tables from Adrumetum was copied from one of the many current books of magic.

25 In this verse a textual variant occurs. In $\mathrm{P}^{38}$ and some other texts the verb exc or ki $\mathbb{z} \mathrm{W}$ has been used. This is also a common word used in magical papyri (Porter 2007:119). 
the power of the God of Paul (Porter 2007:119f). It seems as if there is a direct connection between the 'practices' and the magic practices ${ }^{26}$ and books.

- Again it is a power encounter. Luke points out that God is in command (v 11). He is doing the miracles (healing and exorcism) through his Spirit (cf 13:2f) in the name of Jesus (cf. 19:13; 17). The proclamation of the gospel is powerful. It is victorious over magic. It changes the lives of those people who were involved in magical practices (19:18f).

\section{The Function of Miracles in Acts}

The miracles conducted by Philip and Paul are worked by the Spirit of God, who also confirms the proclamation. The Spirit has been poured out on those who came to faith in Christ (2:17ff), therefore the Jews who do not have the Spirit are not capable of performing miracles. This aspect received special emphasis by the inverted miracle stories: the alleged miracle-workers fail completely. In chapter 19 the miracle working of the sons of the high priest Sceva totally fails, as the demon shows itself superior. The Jews are incapable of performing miracles.

A similar story is encountered in chapter 13. Elymas, the Jew, is regarded as a miracleworker and prophet. His miraculous power is completely unmasked here. He fails and is himself struck blind by Paul's miraculous power. According to Luke the Jews totally fail in their attempts to perform miracles.

The miracles that occur in these texts and elsewhere in Acts are not to accent the miraculous activity (namely healing and exorcism simultaneously in 8:7 and 19:11f) as such, but rather to compliment the preaching of the gospel and to exhibit the proclamation as an irresistible force. The retributive miracle against Elymas at Cyprus is calculated to remove a hindrance to the proclamation, and is part of the teaching of the Lord (13:7f, $12){ }^{27}$ The connection between miracle and word is clear. Luke's composition as a whole then allows no separation of miracle and word. The miracles comprise a secondary part of the teaching and preaching of the apostles, and so the proclamation is legitimized as the word of God. Hence, these works of mercy and power in 8:7 were visible 'signs' confirming the message that Philip proclaimed. In 19:11 Luke tries to point out that the healing effectiveness lays in the powerful name of Jesus (Bruce 1989:368).

\section{Conclusion}

Whatever the exact definition, 'magic' was viewed by the vast majority as something negative and hence useful as a polemical label. In the ancient world 'magic' mostly carried a pejorative connotation. ${ }^{28}$ Therefore, Luke's renunciation of 'magic' (8:19-24; 13:6-12; 10:13-19) was part of a trajectory continuing into the ancient church.

26 Literally, the text means: p r a xei - with a derogatory sense, plural (evil) practices, (bad) habits (RO 8.13); as deceptive actions (magical) practices (AC 19.18) (Friberg 2000:6/6); perier ga - as a substantive magic arts, sorcery, witchcraft (Friberg 2000:2/2).

27 When unbelieving Jews "stirred up the Gentiles and poisoned their minds against the brothers" in Iconium God himself confirms his word, "granting signs and wonders to be done by their hands" (14:3; also cf. 4:25-31; 14:11-18; 16:16-18; 19:13-20).

28 Whatever exact definition would have been given to 'magic,' it was viewed by the vast majority as something negative. 'Magician' was a term of defamation in antiquity. It was what you called your opponent to discredit him (see Philostratus, Life of Apollonius of Tyana; Apollonius of Tyana, Letters 1, 2, 5, 8, 16, 17; Juwenal, Satires 6.542-47; Pliny, Natural History 30.2.11; Justin, Dialogue 69; cf. also Acts 8:9, 11; 13:6). Among the 
Luke is drawing a distinction between magic and miracle. Magic is confined to those who attempted to manipulate the power of God through various means for their own purposes. Miracles, on the other hand, are confined to utilize this power as support for the proclamation of the gospel.

\section{Proclamation of the Word of the Lord in the Graeco-Roman World}

References regarding the proclamation of the word of the Lord occur directly and indirectly nine times $(8: 4,5,12$ (bis), $25 ; 13: 5,7 ; 19: 10,20)$. This high frequency of occurrence of the proclamation of the gospel in these three pericopae, indicates that this is the main focal point in these pericopae. It will be discussed briefly now.

\section{The Proclamation of the Word...}

The 'word of God' (most basic: the word) are among several expressions Luke employs frequently for the content of the gospel itself (see 4:31;13:7, 44; 16:32) (Gaventa (2003:31). The following variations occur in the three pericopae: eujggel izomenoi ton I ogon (8:4); I a I hsant e t on I ogon tou'kuriou (8:25); kat hggel Ion ton I ogon tou' qeou (3:5); akousai ton I ogon tou' qeou' (13:7); akousai ton Iogon tou'kuriou (19:10); t ou'kuriou oll ogo (19:20).

This expression, 'Word of God,' has been used already in the Gospel to describe the proclamation of Jesus and there is proof that this is a phrase used by Luke himself (Lk $5: 1$; $11: 28 ; 22: 61)$. 'Word of God' then, as general reference to the gospel, is used in early Christianity to indicate the continuity between Jesus' proclamation and that of the apostles. In the above pericopae this proclamation is also referred to as 'the word of the Lord' (8:25; $13: 44 ; 19: 10,20)$. In this reference it is sometimes unclear whether Jesus or God is referred to. According to the literary contexts in Acts, as well as its connotation with the Gospel, it can be deduced that the content of the gospel, which revolves around the Messiah (8:5), was referred to by this designation. The character of this message is referred to by Luke as euaggelizw $(8: 12,25)$ - this message was 'good news' to the world. The difference between the Gospel and Acts is that an accent shift has taken place regarding the preaching. Everything that Jesus did and what happened to him have moved to the centre.

This message or good news has also been referred to as the 'kingdom of God' which occurs only seven times $(1: 3 ; 8: 1 ; 14: 22 ; 19: 8 ; 20: 25 ; 28: 23,31)$ in Acts. In 1:3 Luke refers to the resurrected Jesus who spoke for 40 days to his disciples about the kingdom of God. In 14:22 Paul refers to many hardships through which Christians must go 'to enter the kingdom of God'. In 20:25 Paul also refers to the preaching about the kingdom of God in

charges levelled against magicians generally is the use of miracle to gain money for oneself: (a) Aesop (Fables 65); Tacitus (Annals 16.30-32); Apuleius (Apology 67,102; Philostratus (Life of Apollonius of Tyana 6.39 and 8.7. See also Talbert (1997:84) for the negative connotation of magic.

According to Gaventa $(2003: 192)$ the reference to Bar-Jesus as a 'magician' is a signal that Luke associated him with evil. This is verified by Luke's reference to him also as a 'false prophet,' 'son of the devil' and "the enemy of all righteousness, full of all deceit and villainy." A further indication of this negativity is evident from Acts 8 and 13: Simon the magician is referred to as "Repent therefore of this wickedness of yours, and pray to the Lord that, if possible, the intent of your heart may be forgiven you. ${ }^{23}$ For I see that you are in the gall of bitterness and the chains of wickedness." Then there is also the reference to "a certain magician, a Jewish false prophet, named Bar-Jesus" who was referred to by Paul as "You son of the devil, you enemy of all righteousness, full of all deceit and villainy, will you not stop making crooked the straight paths of the Lord?"

Klauck (2000:211) points out magic with positive outcomes. He distinguishes four types of magic: 1) Prophylactic magic; 2) Magic that inflicts harm; 3) Magic to do with love; 4) Revelatory magic. 
the past. In the remaining four texts Luke refers to the preaching of the kingdom of God; in $8: 1$ by Philip and in 19:8 and 28:23, 31 by Paul. Two of these texts $(8: 1 ; 19: 8)$ occur in the three texts under investigation in this research. It has been placed by Luke in the two discourses of exorcisms (chs 8 and 19). This implies that the reference to the preaching of the kingdom of God was important. Luke feels the need to relate this with the events that took place as described in that particular text. In both cases it refers to the source of the authority of the word. God's rule (and power) is stronger than that of the forces of evil.

Jesus declares his exorcisms to be both manifestations and at least partial realizations of God's coming in power to rule his people in the end time (Meier 1994:450). Jesus did not simply speak; he also acted. In his exorcisms, in his formation of an inner circle of disciples, in all his deeds he was 'acting out' his message. From all this we can infer that 'the kingdom of God' is a dynamic event of God coming in power to rule his people in the end time. When Jesus says in Luke that "experiencing his exorcisms is experiencing the kingdom already come" he is making a startling identification: one of his powerful deeds is equated with the powerful action of God (Meier 1994:452). Thus in Jesus' eyes his exorcisms are individual acts of power of God's kingly rule. Thus Jesus makes the kingdom present by his exorcisms and miracles of healing (Meier 1994:453). Jervell (1996:50) points out that "the preaching is confirmed by the miracles, and God testifies to his word by miracles and signs."

\section{Work of the Holy Spirit}

References to the Holy Spirit occur in all three texts. In these texts the Spirit was received when they laid hands on them $(8: 17 ; 13: 3 ; 19: 6)$. Only in 19:6 we find a reference that they also spoke in tongues and prophecied after they received the Spirit.

Gaventa (2003:37) points out that a function of the Spirit in Acts is to empower believers and also to provide evidence that the initiative (for Paul's and Barnabas' journey) lies with God (2003:191). The miracles are worked and determined by the Spirit of God, and so the Spirit confirms the proclamation of the gospel. Because the itinerant Jewish exorcists do not have the Spirit they are not capable of performing miracles (19:13-16). This feature receives special emphasis by the inverted miracle stories: the alleged miracleworker fails completely. In 19:13-20 the miracle-working of the seven sons of the high priest Sceva totally miscarries, as the demon shows itself superior. The Jews are incapable of performing miracles, due to that they no longer have divine authority.

A similar story is encountered in the text of 13:6-12. Elymas, the Jew, is regarded as a miracle worker and prophet $(13: 6)$. He attempts to frustrate faith in Jesus by the proconsul $(13: 8)$. By doing so his alleged miraculous power is completely unmasked. He fails with Paul, and is himself struck blind by Paul's miraculous power $(13: 11,12) .^{29}$ Luke sets forth the weakness of the synagogue by making clear that they cannot perform any miracles, but also that the Jews fail totally in their attempt to perform them (cf. Jervell 1996:93f). They do not possess the Spirit of God.

Thus, after Pentecost, the empowerment of the gospel came through the proclamation of it and sometimes through the performance of miracles which complement $\mathrm{it}^{30}$. Both are

29 Luke is aware that miracles can take place outside the church, but if they do, he regards them as magic and witchcraft, as in the case with Simon Magus (Acts 8:9ff).

30 The apostles (especially Paul) did not perform a miracle every time when he proclaimed the gospel. According to Acts miracles were performed every time when they came in contact with a magician or magical practices (8:4-25; 13:1-12;19:1-20; cf. 5:16;16:16-18). 
performed by the Spirit. It is the Spirit of the Scriptures that is working through the miracles and confirms the kerygma (cf. Jervell 1996:94).

\section{Conclusion}

It became evident that in these three texts Luke juxtaposed miracle and magic within the setting of the proclamation of the gospel. The character and content of the gospel has been spelled out by Luke in his various ways of references to it. In each text the proclamation of the gospel, complimented by the performance of miracles, overpowered the power of evil. This could only realise through the involvement of the Holy Spirit. These successes are emphasized by the references that in each case people came to believe the proclaimed word and that they were amazed, filled with awe, about what they experienced. This proves, according to Luke, the victory of the proclamation of the Gospel over the practice and involvement in evil practices (e.g. magic).

In order to convince the reader Luke made use of a specific rhetorical device which he used in these three texts. This will now briefly be discussed.

\section{A Rhetorical Device in the Ideological Power Play by Luke ${ }^{31}$}

The above discussion gave an orientation about the character of each of the focal events (magic, miracle, proclamation of gospel) which Luke incorporated in his discourse between the proclamation of the Gospel and the response of people, involved in evil practices. This background engenders a better understanding for the success of the power of the Gospel over the power of evil. Now that the reader understands this success, what rhetorical device has been interwoven by Luke into the text to convince the reader to follow the way of the Gospel? This research will focus on the epideictic rhetoric ${ }^{32}$ used by Luke.

In the long tradition of classical rhetoric which goes back to Aristotle and beyond, we find a species of rhetoric labelled 'epideictic' or the rhetoric of 'praise and blame.' When we speak of the rhetoric of praise and blame, we refer to the way the Greeks and Romans continually expressed value judgments of certain persons and their actions by use of the correlative pair of words 'praise and blame' (either kalo; / a i s crot, epaino / y ogo y ekt $0 \forall$, epaino / a i i $0 \sim$ ). The rhetoric of 'praise and blame' focuses on character, which is shown to be either virtuous, and thus honourable, or vicious and thus shameful. ${ }^{33}$ This

31 Not much research has been conducted on the rhetoric of Luke in Acts of the Apostles. In his reference to rhetorical devices in the text of Acts, Conzelmann (1987:xxxvi) only reflected on its occurrence in the speeches, such as: litotes $(12: 18)$, paronomasia $(17: 30 ; 21: 28 ; 24: 3)$, and parechesis $(17: 25 ; 18: 18)$. In his discussion of the occurrence of rhetoric in Acts, Witherington (1998:39-50) relates it to the work of some rhetors in antiquity. He also, as Conzelmann, focuses on the rhetoric in especially the speeches of Paul in Acts. Nothing has been noted about the rhetorical devices referred to in this research. The rhetorical devices will only be referred to due to a restriction of space.

32 Witherington (1998:42) pointed out that rhetoric was essential in the writing of history. Serious histories, according to him, will follow the conventions of deliberative rhetoric, and perhaps also forensic rhetoric, but would largely ignore epideictic rhetoric. In this research the opposite is pointed out.

33 It is quite remarkable how Luke contrasts the protagonists and antagonists in these texts. These contrasts compliment the epideictic rhetoric. The following contrasts occur:

- $\quad$ Philip and Simon contrasted: performing miracles vs. performing greater miracles - Acts 8:5-13;

- Peter and Simon contrasted: Have (received) the Spirit vs. can't have the Spirit - 8:14-25;

- The Proconsul and Elymas contrasted: came to faith vs. rejected faith - 13:1-12;

- Paul and the Jewish exorcists contrasted: Successful and unsuccessful exorcisms - 19:11-20.

Due to a space restriction this subsection could not be discussed but only referred to. 
rhetorical device is clearly sensible in Acts 8, 13 and 19. We will first concentrate on the negative part of this device, namely 'the blame of a person.'

\section{The Denigration of Those involved in Evil}

This part of 'blame' that was proposed and discussed by the Greek philosopher Aristotle in his work Rhetorica (1419.b) and on which Cicero, a Roman philosopher (106-43 BCE), in his work De Oratore $(1.12 .53,1.13 .56,2.43 .182-7)$ and Quintilian, a Roman rhetoritian (35-100 CE), in his work Institutio Oratoria (1.9-10) built, was how to slander one's opponents. In order to slander a person you have to blame (y $0 \mathrm{~g} 0 \sim$ ) him, you must highlight his depravity. This feature is sensible in these three pericopae where Luke uses very negative terminology in order to describe the opponents of Christianity.

- Simon $(8: 9,11)$ and Elymas $(13: 7)$ were referred to as magicians. ${ }^{34}$

- Luke refers to Simon as a wicked person who is in the gall of bitterness and the chains of wickedness (8:22f).

- Simon cannot even pray for himself, but is reduced to seeking mediation from Peter.

- Luke also accuses Elymas as a Jewish false prophet (13:6) and son of the devil. He refers to him as an enemy of all righteousness, full of all deceit and villainy and who is making crooked the straight paths of the Lord.

- Paul refers to the Jews with whom he argued persuasively in a synagogue in Ephesus about the kingdom of God, that some stubbornly refused to believe and speak evil of the Way (19:9); that other Jews and Greeks who practiced magic in Ephesus (19:19), evil spirits came out of them (19:13-16).

- Finally, some itinerant Jewish exorcists tried to use the name of the Lord Jesus over those who had evil spirits but without any success. Thus, in the author's description of the power play, their power is inferior. They are losers.

- The powerful demonstration of those who proclaim the message of the gospel

Under this subsection we will concentrate on the positive side of epideictic rhetoric, namely 'the honourable' or 'noble' $(\mathrm{k} \mid \mathrm{O})$ ). Someone is honourable or noble who can be shown to be good (Rhet. 1.9.3), and goodness resides in actions which reflect virtue (Rhet. 1.9.4). This again is a matter of honour.

\section{Positive Responses to Characterize the Work of the Apostles}

- The crowds with one accord to listen eagerly to the message about the Messiah that was proclaimed by Philip $(8: 6,11) .{ }^{35} \ldots$ But when they believed Philip, who was proclaiming the good news about the kingdom of God and the name of Jesus Christ, they were baptized, both men and women. Even Simon himself believed. After being baptized, he stayed constantly with Philip.

- The proconsul, Sergius Paulus, an intelligent man, who summoned Barnabas and Saul and wanted to hear the word of God (13:7) proclaimed by Paul. When the proconsul saw what had happened, he believed (13:12).

4 It has been indicated that in the ancient world 'magic' mostly carried a pejorative connotation. In the attempt above to define 'magic' it became clear that the contextual meaning here is the technique to manipulating supernatural or supernormal forces to attain one's own ends. In the end these magicians are the 'losers.' 
- Paul argued daily in the lecture hall of Tyrannus. ${ }^{*}{ }^{10}$ This continued for two years, so that all the residents of Asia, both Jews and Greeks, heard the word of the Lord $(19: 9) \cdot{ }^{36}$

- Many of the Jews and Greeks in Ephesus, who became believers, confessed and disclosed their practices. A number of those who practised magic collected their books and burned them publicly (19:18f).

\section{The Work of the Apostles is more Powerful than the Performances of the Magicians}

- The crowds with one accord listened eagerly to what was said by Philip, hearing and seeing the signs that he did, for unclean spirits, crying with loud shrieks, came out of many who were possessed; and many others who were paralysed or lame were cured (8:6f).

- When Paul cursed Elymas that he "will be blind for a while, unable to see the sun, immediately mist and darkness came over him, ..."

- God did extraordinary miracles through Paul, so that when the handkerchiefs or aprons that had touched his skin were brought to the sick, their diseases left them, and the evil spirits came out of them (19:11f).

\section{Reactions of Amazement / Awe/ Astonishment / Joy / Worship Occur}

- There was great joy in that city (8:8) after Philip performed exorcisms and healings.

- Simon was amazed when he saw the signs and great miracles that took place (8:13).

- When the proconsul, Sergius Paulus saw the retributive miracle on Elymas he believed and was astonished at the teaching about the Lord. (13:12).

- All the residents of Ephesus, both Jews and Greeks, were awestruck when the successful exorcisms by Paul and the unsuccessful exorcisms by some itinerant Jewish exorcists became known; and the name of the Lord Jesus was praised (19:17). Awe is an appropriate response to the presence of God (Gaventa 2003:267).

\section{Conclusion}

This section pointed out the geniality of Luke who was competent with a number of rhetorical devices. With the application of these devices he tried to convince his readers about the uselessness of the practices of evil and the power of the Gospel. He also wanted to convince those readers who were still involved in the practices of evil deeds, e.g. magic, to stop it and to become involved in living in accordance to the word of the Lord and to proclaim this gospel to others.

\section{General Conclusion}

It has been pointed out that Luke wanted to convince his readers about the immense power of the Gospel - how the proclamation of the gospel is victorious over the power of evil. In order to achieve this, the research started off with the selection of texts in which references to magic, miracles and the proclamation of the gospel occur. The setting in which these

36 Paul entered the synagogue and for three months spoke out boldly, and argued persuasively about the kingdom of God. When some stubbornly refused to believe and spoke evil of the Way before the congregation, he left them, taking the disciples with him (19:8). 
events had to be interpreted and to be understood was the use of warfare terminology to make the reader aware that these events are part of a cosmic battle in which Christian believers find themselves. The nature of his battle was briefly described, looking at the juxtaposition of magic and miracle, the proclamation of the gospel and the essential involvement of the Holy Spirit. The Spirit contributed to the success of the performance of miracles and the proclamation of the word of God by the different church officials. In order to convince his readers, Luke made use of various rhetorical devices which were interwoven in these texts. The reader and audience had to believe that the gospel of the Kingdom of God is true and has the power to change the lives of people and overcome evil.

\section{BIBLIOGRAPHY}

Alexander, LCA 2005. Acts in its Ancient Literary Context. London: T\&T Clark.

Aune, DE 1980. Magic in Early Christianity pages 1507-57 in Aufstieg und Niedergang der römischen Welt: Geschichte und Kultur Roms im Spiegel der neueren Forsc II/23.2 edited by W Haase. Berlin: de Gruyter.

Barrett, CK 1994. Acts (The International Critical Commentary). Edinburgh: T\&T Clark.

Becker, M 2007. M a g oi - Astrologers, Ecstatics, Deceitful Prophets: New Testament Understanding in Jewish and Pagan Context, pages 87-107 in A Kind of Magic edited by M Labahn \& BJL Peerbolte. London: T\&T Clark.

Bown, C 1976. Magic, in pages 552-562 in DNTT edited by C Brown. Exeter: The Paternoster Press.

Bruce, FF 1989. The Book of the Acts. Grand Rapids: Eerdmans.

Conzelmann, H 1987. Acts of the Apostles (Hermeneia). Philadelphia: Fortress Press.

Crossan, JD 1993. The Historical Jesus: the life of a Mediterranean Jewish peasant. Edinburgh: T\&T Clark.

Danker, FW (ed.) 2000. Greek-English Lexiconof the New Testament and other Early Christian Literature (3rd ed, BDAG). Chicago: The University of Chicago Press.

Deissmann, A 1927. Light from the Ancients East (trans. LRM Strachan). London: Hodder \& Stoughton.

Deissmann, A 1988 [1901]. Bible Studies (transl. A Grieve). Edinburgh: T\&T Clark.

Delling, G 1967. M a gei , ma geuw in pages 356-9 in TDNT (vol 4) edited by G Kittel. Grand Rapids: Eerdmans.

Dunn, JDG 1996. The Acts of the Apostles (Narrated Commentaries). Edinburgh: T\&T Clark.

Fox, RB 1987. Pagans and Christians. New York: Knopf.

Frazer, JG 1978. The illustrated golden bough. London: Macmillan.

Friberg, T, Friberg, B \& Miller, NF 2000. Analytical Lexicon of the Greek New Testament (Vol. 4). Grand Rapids: Baker Books. (Logos electronic edition).

Garrett, S 1989. The demise of the Devil: magic and the demonic in Luke's writings. Minneapolis: Fortress Press.

Gaventa, VR 2003. Acts (Abingdon New Testament Commentaries). Nashville: Abingdon Press. 
Grundmann, W 1995. Duna mi , pages 283-316 in TDNT edited by G Kittel. Grand Rapids: Eerdmans. (Electronic Logos edition).

Guthrie, D 1981. New Testament Theology. Leicester: Intervarsity Press.

Haenchen, E 1971. The Acts of the Apostles. Oxford: Basil Blackwell.

Holmén, T 2007. Jesus and Magic: Theodicean Perspectives to the Issue, pages 43-56 in A Kind of Magic edited by M Labahn \& BJL Peerbolte. London: T\&T Clark.

Hull JHE 1967. The Holy Spirit in the Acts of the Apostles. London: Lutterworth Press.

Hull, JM 1974. Hellenistic Magic and the Synoptic Tradition (Studies in Biblical Theology, second series 28). London: SCM Press LTD.

Hurtado, LW 2003. Lord Jesus Christ. Grand Rapids: Eerdmans.

Jervell, J 1996. The Theology of the Acts of the Apostles (New Testament Theology). Cambridge: University Press.

Josephus, F \& Whiston, W (1996, c1987). The works of Josephus: Complete and unabridged. Includes index. (Life 1-6). Peabody: Hendrickson. (Electronic Logos edition).

Josephus, F \& Whiston, W (1996, c1987). The works of Josephus: Complete and unabridged. Includes index. (Ant 1-4). Peabody: Hendrickson. (Electronic Logos edition).

Kanda, SH 1976. The form and the function of the Petrine and Pauline miracle stories in the Acts of the Apostles. (Unpublished PhD Graduate School Claremont).

Käsemann, E 1942-3. Die Legitimät des Apostels. ZNW, 33-71).

Klauck, H-J, 2000a. Magic and Paganism in Early Christianity. Edinburgh: T\&T Clark.

Klauck, H-J 2000b. The Religious Context of Early Christianity. Edinburgh: T\&T Clark.

Labahn, M \& Peerbolte, BJL (eds.) 2007. A Kind of Magic. London: T\&T Clark.

Ladd, GE 1974. A Theology of the New Testament. Grand Rapids: Eerdmans.

Lenski, RCH 1961. The Interpretation of the Acts of the Apostles. Minneapolis: Augsburg Publishing House.

Louw, JP \& Nida, EA 1988. Greek-English Lexicon (vol 1). New York: United Bible Societies.

Munck, J 1981. The Acts of the Apostles. New York. Doubleday \& Company, Inc.

Marguerat, D 2002. The First Christian Historian: Writing the "Acts of the Apostles" (SNTS Monograph series 121). Cambridge: University Press.

Marston, JM 2007. Language of Ritual Cursing in the Binding of Prometheus. Greek, Roman, and Byzantine Studies 47, 121-133.

Meier, JP 1994. A Marginal Jew: Rethinking the Historical Jesus (Vol II, Mentor, Message, and Miracles). London: Doubleday.

Munck, J 1981. The Acts of the Apostles. New York: Doubleday \& Company, Inc.

Newman, BM \& Nida, EA 1972. A Translator's Handbook on the Acts of the Apostles. London: United Bible Societies.

Ogliatti, DP 2007. From ma gei to Magic. Envisaging a Problematic Concept in the Study of Religion, pages 3-19 in A Kind of Magic edited by M Labahn \& BJL Peerbolte. London: T\&T Clark.

Pilch, JJ 2004. Visions and Healing in the Acts of the Apostles (How the Early Believers Experience God). Collegeville: Liturgical Press. 
Porter, SE 2007. Magic in the Book of Acts, pages 107-122 in A Kind of Magic edited by M Labahn \& BJL Peerbolte. London: T\&T Clark.

Reimer, AM 2007. Miracle and Magic: A Study in the Acts of the Apostles and the Life of Apollonius of Tyana (JSNTSup, 235) Sheffield: Sheffield Academic Press.

Remus, H 1983. Pagan-Christian conflict over miracle in the second century. Cambridge: Philadelphia Patristic Foundation.

Sanders, EP 1985. Jesus and Judaism. Philadelphia: Fortress Press.

Smith, M 1998. Jesus the Magician: Charlatan or Son of God? Berkeley: Seastone.

Spencer, FS 1997. Acts. Sheffield: Sheffield Academic Press.

Strelan, R 2004. Strange Acts (Studies in the Cultural world of the Acts of the Apostles). Berlin: De Gruyter.

Talbert, CH 1997. Reading Acts. A Literary and Theological Commentary on the Acts of the Apostles. New York: Crossroad Publishing Company.

Twelftree, GH 2007. Jesus the Exorscist and Ancient Magic, pages 57-86 in A Kind of Magic edited by M Labahn \& BJL Peerbolte. London: T\&T Clark.

Whiston, W 1996. The Works of Josephus: Complete and Unabridged (Ant 8.42-49). Peabody: Hendrickson. (Electronic Logos edition).

Witherington, B 1998. The Acts of the Apostles. A Socio-Rhetorical Commentary. Grand Rapids: Eerdmans.

Zmijewski, J 1994. Die Apostelgeschichte. Printed in Germany: Verlag Friedrich Pustet Regensburg. 